Tinjauan Pustaka

\title{
PERANAN DURASI QRS DAN SKOR QRS SELVESTER DALAM KEBERHASILAN REPERFUSI MIOKARD
}

\author{
Yose Ramda Ilhami
}

\begin{abstract}
Abstrak
Perubahan gambaran elektrokardiogram (EKG) terjadi pada fase akut IMA EST baik berupa perubahan repolarisasi ataupun perubahan depolarisasi. Skor QRS Selvester dan pemanjangan kompleks QRS merupakan parameter yang digunakan untuk memperkirakan luas infark dan penilaian iskemia. Tujuan penulisan ini adalah untuk mengetahui mekanisme perubahan durasi QRS dan skor QRS Selvester setelah reperfusi yang optimal. Penulisan artikel ini berdasarkan studi kepustakaan yang terkait dengan peranan durasi QRS dan skor QRS Selvester serta keberhasilan reperfusi miokard. Iskemia mengakibatkan perubahan gambaran listrik sel miokard normal, sehingga terjadi perubahan gambaran EKG yaitu meliputi perubahan gelombang T, elevasi segmen ST dan distorsi dengan pemanjangan kompleks QRS. Penilaian luas infark dapat dilakukan dengan menilai skor QRS Selvester. Iskemia juga mengakibatkan pemanjangan kompleks QRS melalui pemanjangan konduksi purkinye dan blok peri-infark. Reperfusi optimal dapat mengakibatkan regresi gelombang $Q$ dan penurunan durasi kompleks $Q R S$. Perubahan skor QRS selama reperfusi masih kontroversial. Perubahan pada durasi QRS dan skor QRS Selvester sebelum dan setelah reperfusi menandakan bahwa parameter ini merupakan parameter dinamis yang akan berubah ketika terjadinya reperfusi yang optimal pada tingkat seluler.
\end{abstract}

Kata Kunci: durasi QRS, skor QRS Selvester, reperfusi

\begin{abstract}
Changes in Electro Cardiogram (ECG) occur in acute phase of STEMI either as repolarization or depolarization change. Selvester QRS score and lengthening of QRS complex duration are parameters that is used to predict infarct size and to analyze ischemia. The purpose of this literature review is to understand the mechanism of change in QRS duration and Selvester QRS score after optimal reperfusion. Ischemia causes changes in the electrical feature of normal myocardial cells including changes in the $T$ wave, ST segment elevation and distortion with prolongation QRS complex. Assessment of infarct size can be done by assessing Selvester QRS score. Ischemia also resulted in prolongation of the QRS complex with elongation of Purkinje conduction and peri-infarction block. Optimal reperfusion may lead to regression of the $Q$ wave and a decrease in the duration of the QRS complex. QRS score changes during reperfusion remains controversial. Changes in QRS duration and Selvester QRS score before and after reperfusion indicates that these parameters are dynamic parameters that will change when the optimal reperfusion occurs at the cellular level.
\end{abstract}

Keywords: QRS duration, Selvester QRS score, reperfusion

Afiliasi Penulis : Bagian Fisiologi Fakultas Kedokteran Universitas Andalas Padang, Korespondensi: Yose Ramda Ilhami, Bagian Fisiologi Fakultas Kedokteran Universitas Andalas, Jl. Peritis Kemerdekaan No. 94, PO BOX 49 Padang 25127. Email: yose_milanisti@yahoo.co.id, Telp: 082174851185 


\section{PENDAHULUAN}

Penyakit arteri koroner masih menjadi penyebab kematian paling sering diseluruh dunia. Infark miokard akut dengan elevasi segmen ST (IMA EST) merupakan salah satu manifestasi klinis dari penyakit arteri koroner. ${ }^{1}$ Fase akut IMA EST terjadi perubahan gambaran EKG baik perubahan repolarisasi ataupun depolarisasi. Perubahan gambaran EKG ini diawali dengan adanya perubahan pada gelombang $T$ (hiperakut T) dan diikuti dengan elevasi segmen ST baik dengan atau tanpa distorsi kompleks QRS. Perubahan ini disebabkan oleh adanya gangguan pada aktivitas listrik miokard yang mengalami iskemia. ${ }^{2,3}$

Skor QRS Selvester merupakan salah satu skor kerusakan pada miokard yang sudah diinvestigasi pada berbagai penelitian. Skor ini dikembangkan untuk memperkirakan infark miokard, sangat prediktif terhadap luasnya infark anterior akut dan proporsional terhadap abnormalitas gerakan dinding miokard dan berbanding terbalik dengan fraksi ejeksi berdasarkan ventrikulografi. ${ }^{4,5}$

Analisis pada segmen ST telah divalidasikan menjadi penanda patensi arteri koroner epikardial selama terapi IMA-EST dan bahkan sebagai penanda perfusi jaringan miokard. Sementara perubahan pada morfologi kompleks QRS selama ini menandakan adanya nekrosis miokard. ${ }^{6}$ Penurunan durasi QRS lebih banyak terjadi pada pasien dengan reperfusi yang optimal dibandingkan yang tidak optimal yang menandakan pemanjangan durasi QRS sebagai suatu fenomena dinamis yang akan membaik seiring reperfusi yang optimal. $^{3}$ Tujuan penulisan tinjauan pustaka ini adalah untuk mengetahui mekanisme perubahan durasi QRS dan skor QRS Selvester setelah reperfusi yang optimal.

\section{METODE}

Penulisan tinjauan pustaka ini berdasarkan studi kepustakaan yang terkait dengan peranan durasi QRS dan skor QRS Selvester serta keberhasilan reperfusi miokard.

\section{HASIL DAN PEMBAHASAN}

\section{Gambaran EKG pada Iskemia Miokard}

Aktivasi ventrikel merupakan hasil dari dua kondisi yang terjadi secara overlapping, yakni aktivasi endocardium dan aktivasi transmural. Aktivasi endokard mengikuti suatu distribusi anatomis dan fisiologis dari sistem HisPurkinye, yang menghasilkan aktivasi secara simultan dari banyak lokasi pada endokard serta menyebabkan depolarisasi hampir seluruh permukaan endokardium dari kedua ventrikel dalam

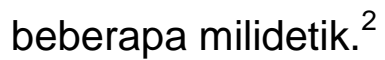

Urutan aktivasi endokardium digambarkan pada gambar 1. Aktivitas awal bermula pada tiga posisi: (1) dinding paraseptal anterior ventrikel kiri; (2) dinding paraseptal posterior ventrikel kiri; dan (3) pertengahan dari septum sebelah kiri. Lokasi-lokasi ini sesuai dengan lokasi insersi ketiga cabang berkas cabang kiri. Aktivitas menyebar dari lokasi tersebut ke arah anterior dan inferior kemudian superior untuk mengaktifkan dinding anterior dan lateral ventrikel kiri. Daerah posterobasal ventrikel kiri merupakan daerah yang 
terakhir diaktivasi. Aktivasi septum berawal pada bagian tengah pada sisi kiri dan menyebar sepanjang septum dari kiri ke kanan dan dari apex ke basis. ${ }^{2}$

Aktivasi ventrikel kanan bermula di dekat lokasi insersi berkas cabang kanan di dekat basis muskulus papilaris anterior dan kemudian menyebar ke dinding bebas ventrikel kanan. Aktivasi endokard pada kedua ventrikel secara keseluruhan bermula pada permukaan septum dan menyebar ke bawah dan mengelilingi dinding bebas ventrikel kanan ke daerah posterior dan basal, dengan arah dari apex ke basis. ${ }^{2}$ Aktivasi kemudian bergerak dari endokard ke epikard. Aktivasi endokard berawal pada pertemuan antara Purkinye dengan otot ventrikel dan bergerak dengan konduksi sel otot ke sel otot dengan arah oblik menuju epikard. ${ }^{2}$

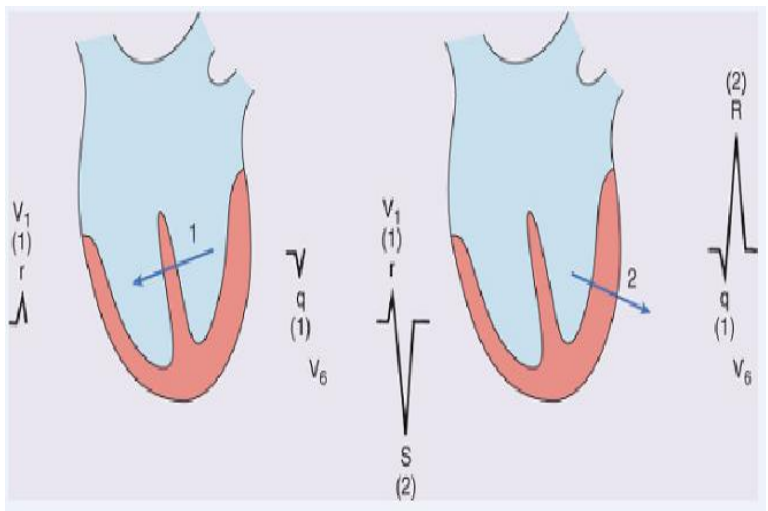

Gambar 1. Ilustrasi Skematik Depolarisasi Ventrikel sebagai dua vektor sekuensial, mewakili aktivasi septal (gambar kiri) dan aktivasi dinding bebas ventrikel kiri (gambar kanan). Gambaran gelombang QRS pada lead V1 dan V6 yang ditimbulkan oleh masingmasing aktivasi. ${ }^{2}$

Pola aktivasi yang kompleks ini dapat disederhanakan menjadi dua vektor: (1) aktivasi septum dan (2) aktivasi dinding bebas ventrikel kiri (gambar 1). Aktivasi awal septum interventrikel menghasilkan vektor dengan arah dari kiri ke kanan pada potongan frontal serta ke arah anterior pada potongan horizontal, sesuai posisi anatomi septum dalam dinding dada. Vektor ini menghasilkan bagian awal dari kompleks QRS dengan amplitude yang kecil dan durasi yang singkat (kurang dari 30 milidetik). Bagian dari kompleks QRS selanjutnya menggambarkan aktivasi dari dinding bebas ventrikel kiri dan kanan. Karena massa otot ventrikel kanan yang jauh lebih kecil daripada ventrikel kiri, ia hanya memberikan sebagian kecil dari kompleks QRS yang terekam pada EKG standard, sehingga kompleks QRS dianggap "hanya" mewakili aktivitas ventrikel kiri pada keadaan normal. $^{2}$

Iskemia memiliki efek terhadap gambaran listrik sel miokard. Iskemia berat yang akut dapat menurunkan potensial membran istirahat, memperpendek durasi potensial aksi pada area iskemik dan menurunkan kecepatan peningkatan dan amplitude fase 0 . Perubahan ini menimbulkan adanya perbedaan tegangan antara area normal dan area iskemik yang mengakibatkan adanya arus listrik antara area tersebut. Arus listrik yang dihasilkan oleh cidera jaringan ini ditampilkan pada EKG dengan deviasi segmen ST. Gambaran EKG yang ditemukan pada fase iskemia berat yang akut adalah adanya deviasi segmen ST sebagai akibat mekanisme aliran listrik pada cidera miokard. ${ }^{2}$ Pada kondisi normal, segmen ST biasanya mencapai keadaan isoelektrik karena hampir semua sel miokard sehat memiliki potensial yang 
sama selama fase insial dan fase pertengahan repolarisasi. $^{7}$

Sesaat setelah oklusi arteri koroner, perubahan EKG dapat dideteksi pada sadapan yang menghadap area iskemik. Pada awalnya gelombang $\mathrm{T}$ akan menjadi tinggi, simetris dan memiliki puncak (iskemia derajat I). Kemudian terdapat elevasi segmen ST tanpa adanya distorsi dari ujung kompleks QRS (iskemia derajat II). Terakhir didapatkan adanya distorsi pada ujung kompleks QRS (iskemia derajat III) yang disebabkan oleh adanya pemanjangan konduksi listrik pada serabut Purkinje pada area iskemik. ${ }^{3}$

Serabut Purkinje relatif kurang sensitif terhadap iskemia dibandingkan miosit, sehingga untuk terjadinya gangguan pada akhir kompleks QRS, harus ada suatu proses iskemi yang berat dan lama yang bisa mempengaruhi serabut Purkinje. Pada pasien dengan sirkulasi kolateral, tidak ditemukan adanya perubahan pada kompleks QRS selama angioplasti. Tidak adanya distorsi bagian terminal kompleks QRS pada iskemi yang lama, bisa merupakan salah satu tanda proteksi miokard (mungkin karena adanya aliran miokard yang persisten atau preconditioning miokard). ${ }^{3}$

Walaupun transisi antara derajat iskemia sifatnya gradual dan berkelanjutan, untuk tujuan praktik klinis iskemia derajat II didefinisikan sebagai adanya elevasi segmen $\mathrm{ST} \geq 0,1 \mathrm{mV}$ tanpa distorsi bagian terminal kompleks QRS dan derajat III sebagai elevasi segmen ST dengan distorsi bagian terminal kompleks QRS (pertemuan titik $\mathrm{J} \geq 50 \%$ dari gelombang $\mathrm{R}$ pada sadapan dengan konfigurasi $\mathrm{qR}$, atau hilangnya gelombang $S$ pada sadapan dengan konfigurasi Rs, seperti ditunjukkan oleh gambar 2. Akan tetapi, hanya minoritas pasien dengan infark miokard akut menunjukkan iskemia derajat III pada awal masuk. $^{3}$

Defleksi awal yang abnormal pada infark miokard disebabkan oleh hilangnya tegangan yang dihasilkan oleh jaringan infark. Gelombang Q epikardial disebabkan oleh adanya transmisi pasif dari potensial didalam rongga melalui jaringan miokard yang tidak aktif secara elektrik. $^{8}$

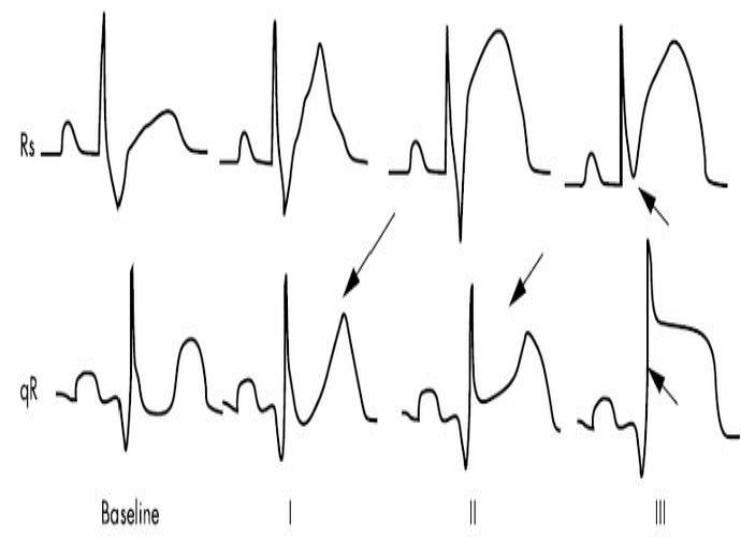

\section{Gambar 2. Derajat Iskemia pada Pola EKG Rs dan $q R^{3}$}

Defleksi awal yang abnormal pada infark miokard disebabkan oleh hilangnya tegangan yang dihasilkan oleh jaringan infark. Gelombang $Q$ epikardial disebabkan oleh adanya transmisi pasif dari potensial didalam rongga melalui jaringan miokard yang tidak aktif secara elektrik. ${ }^{8}$

Gelombang $\mathrm{Q}$ terbentuk dalam 6 hingga 14 jam (rerata 9 jam) setelah onset gejala. Gelombang $Q$ sering muncul ketika segmen ST masih elevasi dan menetap untuk beberapa hari, minggu, bulan atau tahun dan bisa sampai selamanya. ${ }^{8}$ 
Abnormalitas pada bagian tengah atau bagian akhir kompleks QRS dapat disebabkan oleh perubahan urutan aktivasi atau adanya aktivasi yang lambat didalam atau diluar jaringan infark. Durasi QRS akan tetap tidak berubah jika infark mempengaruhi bagian ventrikel yang diaktivasi pada akhir secara normal dan mempengaruhi gambaran aktivasi tetapi tidak menyebabkan perlambatan konduksi. Pada pasien infark miokard dengan abnormalitas bagian akhir kompleks QRS, durasi QRS meningkat. ${ }^{8}$

Nilai batas atas normal untuk durasi QRS umumnya adalah 120 milidetik (dan beberapa literatur mengatakan 110 milidetik). Wanita umumnya memiliki durasi QRS yang lebih pendek daripada pria (5 sampai 8 milidetik). ${ }^{2}$ Pada keadaan normal, durasi QRS dinilai pada lead dengan durasi QRS yang paling panjang. ${ }^{2}$ Sedangkan pada keadaan iskemia miokard, berbagai metode telah digunakan untuk menghitung durasi QRS: durasi QRS yang paling panjang ${ }^{9,10}$, rerata durasi QRS pada lead-lead sesuai infark (lead I, avL, V1-V6 untuk infark anterior serta lead II, III, aVF, V5, V6 untuk infark inferior $)^{11}$, rerata durasi QRS pada leadlead dengan elevasi segmen $\mathrm{ST}^{12}$, durasi QRS terpendek pada lead tanpa deviasi segmen $S T^{13}$, lead tunggal tertentu (lead II) ${ }^{7}$, dan dua lead tertentu (lead V2 dan V5) ${ }^{14}$. Namun sampai saat ini belum ditentukan metode penggunaan lead yang optimal untuk pengukuran durasi QRS pada keadaan iskemia miokard.

Defek pada konduksi ventrikel
setelah infark miokard pertama
dideskripsikan oleh Oppenheim dan
Rotschild pada tahun 1917. Perlambatan

konduksi dihasilkan baik dari interupsi konduksi pada ujung akhir serabut Purkinje yang dikenal dengan arborization block, atau oleh adanya pemendekan konduksi pada miokard. First pada tahun 1950, memperkenalkan istilah blok periinfark untuk menjelaskan adanya pola infark miokard dimana adanya abnormalitas QRS awal (gelombang Q) yang diikuti dengan adanya defleksi akhir yang lambat. ${ }^{8}$

Kriteria diagnosis blok periinfark dikeluarkan oleh Grant, meliputi: 1) karakteristik abnormalitas dari bagian awal kompleks QRS (gelombang Q), 2) adanya arah listrik kompleks ujung QRS melalui daerah infark dengan sudut antara arah listrik kompleks QRS awal dan akhir lebih dari 100 derajat dan 3) dijumpai adanya pemanjangan kompleks QRS. Pola EKG ini tidak spesifik untuk infark, karena ini kadang berhubungan dengan adanya fibrosis miokard. Keberadaan blok arborisasi menjadi dipertanyakan karena infark pada anjing tidak mengganggu morfologi aliran listrik serabut Purkinje, walaupun aliran listrik ini terjadi setelah onset kompleks QRS. ${ }^{8}$

Vassallo dkk menemukan bahwa pola aktivasi endokardial normal pada pasien dengan infark miokard inferior dan durasi QRS rerata 164 ms. Pada studi yang sama, pola aktivasi endokard normal atau tertunda pada daerah infark passion dengan infark miokard anterior dan durasi QRS rerata 144 ms. Studi ini mengemukakan bahwa keterlambatan konduksi pada infark miokard terlokalisasi tidak pada sistem konduksi akan tetapi pada miokardium. ${ }^{8}$

Kemampuan EKG dalam menilai keadaan pada miokard sudah dikenal sejak lama dan memiliki korelasi yang baik dengan temuan otopsi. Terdapat 
beberapa faktor yang mempengaruhi akurasi EKG untuk mengenali dan mengetahui lokasi infark miokard, diantaranya : 1) dimensi infark, 2) lama terjadinya infark, 3) ketebalan dinding ventrikel yang terlibat, 4) lokasi infark, 5) ada tidaknya infark multipel, 6) ada tidaknya hipertrofi atau dilatasi ventrikel dan 7) ada tidaknya abnormalitas konduksi ventrikel. ${ }^{8}$

Selvester dkk mengembangkan sistem skor QRS berdasarkan urutan aktivasi ventrikel normal yang membagi ventikel menjadi 20 segmen dan mensimulasikan hilangnya miokard yang aktif dengan menghilangkan satu atau lebih segmen secara model komputer. Dengan menggunakan modifikasi metode ini, Wagner dkk mengembangkan kriteria untuk memperkirakan ukuran infark miokard dari EKG 12 sadapan standar. Mereka menemukan bahwa sistem skor QRS dengan 29 poin memiliki spesifisitas $98 \%$ pada populasi untuk tidak menderita infark miokard. ${ }^{8}$

Selvester mengembangkan suatu sistem skor QRS berdasarkan perubahan pada aktivasi jantung normal yang disebabkan oleh infark. Sistem skor ini menggunakan 50 kriteria / 31 poin untuk memperkirakan ukuran miokard yang mengalami infark berdasarkan kriteria QRS pada sadapan aVL, I, II, aVF dan V1 hingga V6. Setiap poin dikembangkan untuk menggambarkan infark sebesar $3 \%$ dari semua massa ventrikel kiri. $^{15}$

Skor QRS mampu mengestimasi luas, dalam dan lokasi infark berdasarkan penilaian bagian awal kompleks QRS. Terdapat beberapa faktor yang menghambat kemampuan nilai prediktif EKG ini, antara lain : 1) gangguan konduksi intraventrikular, 2) hipertrofi miokard yang mengelilingi jejas miokard, 3) hilangnya daya elektrik akibat infark dari area lain, 4) adanya revitalisasi daerah miokard yang mengalami stunning atau hibernating, 5) bisa terjadinya perluasan infark akibat peregangan dinding miokard, 6) peningkatan volume intravaskuler, 7) adanya gelombang $Q$ yang transien selama infark miokard akut, 8) faktor lainnya yang mempengaruhi. ${ }^{8}$

\section{Pengaruh Reperfusi pada Gambaran EKG}

Selama stadium awal reperfusi, penurunan amplitudo gelombang $\mathrm{R}$ atau terjadinya akselerasi pembentukan gelombang $Q$, akan tetapi setelah 12 jam atau lebih gelombang $Q$ akan menjadi lebih kecil atau hanya muncul pada sadapan yang lebih sedikit dan berkurangnya amplitudo gelombang $Q$ menjadi kurang jelas pada pasien dengan reperfusi dibandingkan tanpa reperfusi. Ratt dkk menemukan bahwa adanya gelombang $Q$ abnormal pada fase awal infark miokard akut tidak memperkecil keuntungan berkurangnya ukuran infark setelah terapi trombolitik. Sebaliknya, regresi gelombang $Q$ pada pasien dengan infark anterior yang menjalani terapi trombolitik masih kontroversial. Pada beberapa studi ditemukan tidak ada korelasi dengan perbaikan fungsi ventrikel kiri dan tidak memiliki signifikansi secara prognostik, sementara pada studi lain terdapat studi adanya hubungan antara regresi gelombang $Q$ dengan perbaikan fungsi ventrikel kiri. Pada pasien yang diterapi dengan angioplasti adanya distorsi pada bagian akhir QRS berhubungan dengan luaran klinis yang lebih jelek. ${ }^{8}$ 
Skor Selvester dikembangkan untuk memperkirakan ukuran infark. Skor ini telah divalidasi pada pasien dengan lokasi infark yang berbeda pada studi post mortem dan telah dibandingkan dengan ukuran dan lokasi infark dengan MRI. Walaupun skor Selvester hanya divalidasi untuk digunakan setelah fase akut infark miokard, skor ini digunakan juga untuk memonitor perkembangan abnormalitas QRS selama fase akut. Skor Selvester memiliki hubungan yang signifikan terhadap miokard yang berrisiko infark dengan SPECT $(r=0,49) .^{15}$

Ilkay dkk menemukan adanya durasi QRS yang lebih panjang dan pemendekan yang lebih sedikit setelah angioplasti pada 60 menit setelah angioplasty, pada pasien dengan reperfusi yang tidak optimal dibandingkan dengan reperfusi optimal, yang menandakan adanya fenomena dinamis dari durasi QRS selama iskemia dan reperfusi, yang menandakan pemanjangan durasi QRS selama iskemia dan resolusi dari pemanjangan yang mengikuti reperfusi yang berhasil pada tingkat seluler. ${ }^{16}$ Weston yang menilai oklusi koroner pada anjing menemukan bahwa terdapat pemanjangan durasi QRS dan efek sampingnya terhadap kerusakan miokard. ${ }^{6}$ Pada studi lain, Cantor dkk menemukan pemanjangan $\mathrm{QRS} \geq 3 \mathrm{~ms}$ terjadi pada 42 dari 51 pasien yang menjalani intervensi koroner perkutan dan lebih besar pada oklusi segmen proksimal dan tengah dari arteri utama. ${ }^{14}$ Tsukahara dkk melaporkan terjadinya normalisasi durasi QRS dalam 24 jam setelah angioplasti yang berhasil pada 79\% pasien yang memiliki durasi QRS yang memanjang (gambar 3$).^{13}$
Suzuki dkk menunjukkan peranan durasi QRS awal sebagai petanda fenomena no-reflow pada pasien-pasien dengan infark miokard akut dengan obstruksi arteri koroner kiri akut. Pada kelompok pasien dengan fenomena noreflow, terdapat durasi QRS awal yang lebih panjang dibandingkan dengan kelompok dengan normal reflow (134 \pm 22 milidetik vs $96 \pm 22$ milidetik; $p=0,004)$, sedangkan elevasi segmen ST tidak berbeda pada kedua kelompok. $^{17}$

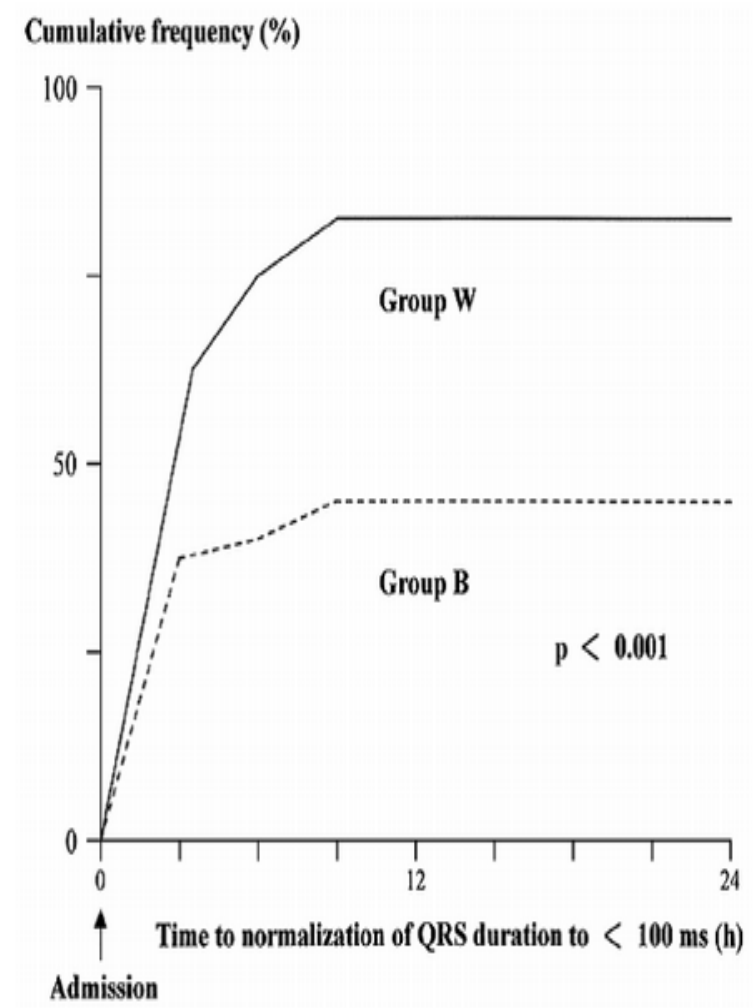

\section{Gambar 3. Waktu Normalisasi Durasi QRS. ${ }^{11}$}

Normalisasi durasi QRS sebagian besar terjadi dalam 3 jam baik pada grup W (durasi QRS >100 ms tanpa blok berkas cabang) ataupun grup B (dengan blok berkas cabang). ${ }^{11}$ Pada pasienpasien STEMI yang dilakukan fibrinolitik, Kacmaz dkk menemukan bahwa pada 
EKG awal tidak terdapat perbedaan tinggi elevasi segmen ST pada kelompok dengan reperfusi tidak optimal maupun reperfusi optimal pasca fibrinolitik, namun pada kelompok dengan reperfusi tidak adekuat terdapat durasi QRS yang lebih panjang pada EKG awal $(91 \pm 11$ vs $79 \pm 11$ milidetik; $p<0,001$ ) serta pemendekan durasi QRS yang lebih sedikit $(5 \pm 4$ vs $18 \pm 5$ milidetik; $p<$ $0,001)$ dibandingkan pada kelompok dengan reperfusi yang adekuat. ${ }^{12}$

Maden dkk menemukan bahwa durasi QRS awal yang lebih panjang merupakan prediktor independen terhadap terjadinya fenomena no-reflow pada pasien-pasien yang menjalani angioplasti primer. Kedua kelompok memiliki elevasi segmen ST yang sama, namun kelompok pasien dengan fenomena no-reflow memiliki durasi QRS awal yang lebih panjang dibandingkan dengan kelompok dengan aliran normal (84 [IQR 80-93] milidetik vs 76 [IQR 6080] milidetik; $p<0,001)$ Setelah angioplasti primer, durasi QRS tetap lebih panjang pada kelompok dengan no-reflow dibandingkan dengan kelompok aliran normal (81 [IQR 75-90] milidetik vs 60 [IQR 48-69] milidetik; $p<0,001)$, dengan pemendekan durasi QRS yang lebih nyata pada kelompok aliran normal. Peneliti juga menemukan usia, durasi iskemia dan durasi QRS awal sebagai petanda independen terhadap terjadinya no-reflow pasca angioplasti primer. Peneliti mengusulkan durasi QRS awal sebesar 78 milidetik sebagai titik potong untuk memprediksi fenomena no-reflow, dengan sensitivitas $81 \%$ dan spesifitas $51 \%$. $^{11}$

Adanya gelombang $Q$ tidak selalu menandakan adanya nekrosis transmural yang irreversibel. Gelombang $Q$ dapat bersifat sementara dan menggambarkan adanya kerusakan miokard yang berat tetapi masih reversibel, yang menandakan adanya miokard yang mengalami stunning atau hibernating. Pada suatu serial kasus didapatkan 3 orang pasien dengan gelombang $Q$ yang dalam pada awal masuk dan menjalani terapi fibrinolitik, mengalami perbaikan gejala dan munculnya kembali gelombang $Q$ pada 8-12 jam setelah terapi fibrinolitik. ${ }^{18}$

Beberapa studi menilai hubungan antara MRI jantung dan skor QRS Selvester pada pasien IMA-EST yang menjalani reperfusi. Korelasi yang baik ditemukan antara ukuran infark antara MRI jantung dan skor QRS yang diukur pada waktu 8 hari setelah reperfusi pada 29 pasien. Pada penelitian lainnya dari 31 paeien dengan IMA-EST yang dilakukan IKPP dengan ukuran infark rerata dari MRI kardiak sebesar $12,7 \%$, ditemukan ukuran infark berdasarkan skor QRS yang lebih besar dibandingkan dengan yang didapat berdasarkan MRI jantung pada 48 jam, 1 dan 6 bulan. ${ }^{19}$

Knippenberg dkk menemukan bahwa terjadi estimasi berlebih dari ukuran infark dengan menggunakan skor QRS Selvester dibandingkan dengan MRI-delayed enhancement pada pasien yang menjalani reperfusi yang menandakan adanya ketidakmampuan EKG dalam menilai miokardium yang masih mengalami stunning dan hibernating. ${ }^{20}$

\section{SIMPULAN}

Gambaran elektrokardiogram saat iskemia miokard memiliki mekanisme tersendiri terhadap terjadinya pemanjangan durasi QRS, dan aktivasi yang 
terlambat pada kompleks QRS yang menimbulkan adanya gelombang $Q$. Perubahan pada durasi QRS dan skor QRS Selvester sebelum dan setelah reperfusi menandakan bahwa dua parameter ini merupakan parameter dinamis yang akan berubah ketika terjadinya reperfusi yang optimal pada tingkat seluler.

\section{DAFTAR RUJUKAN}

1. Steg PG, James SK, Atar D, Badano LP, Blomstrom-Lundqvist C, Borger MA et al. ESC guideline for the management of acute myocardial infarction in patients presenting with STsegment elevation. Eur Heart J 2012;33:2569-619

2. Mirvis $\mathrm{DM}$, Goldberger $\mathrm{AL}$. Electrocardiography. In: Bonow RO, Mann DL, Zipes DP, Libby $P$, eds. Braunwald's Heart Disease A Textbook of Cardiovascular Medicine. $9^{\text {th }}$ ed. Philadelphia: Elsevier Saunders; 2012:126-67.

3. Birnbaum $Y$, Drew BJ. The electrocardiogram in ST elevation acute myocardial infarction: correlation with coronary anatomy and prognosis. Postgrad Med J 2003;79:490-504.

4. Richardson K, Engel G, Yamazaki T, Chun S, Froelicher VF. Electrocardiographic damage scores and cardiovascular mortality. Am Heart J. 2005;149:458-63.

5. Strauss DG, Selvester RH, Lima JAC, Arheden $\mathrm{H}$, Miller JM, Gerstenblith $\mathrm{G}$ et al. ECG quantification of myocardial scar in cardiomyopathy patients with or without conduction defects: correlation with cardiac magnetic resonance and arrhthmogenesis. Cir Arrhythm Electrophysiol 2008;1(5): 327-36

6. Weston $P$, Johanson $P$, Schwartz LM, Maynard C, Jennings RB, Wagner GS.
The value of both ST-segment and QRS complex changes during acute coronary occlusion for prediction of reperfusioninduced myocardial salvage in canine model. J Electrocardiol 2007;40:18-25

7. Canty JM. Coronary Blood Flow and Myocardial Ischemia. In: Bonow RO, Mann DL, Zipes DP, Libby $P$, eds. Braunwald's Heart Disease. A Textbook of Cardiovascular Medicine. $9^{\text {th }}$ ed. Philadelphia Elsevier Saunders 2012:1049-75.

8. Surawicz B, Knilans T. Myocardial infarction and electrocardiographic patterns simulating myocardial infarction. In Chou's Electrocardiography in Clinical Practice: Adult and Pediatric. $6^{\text {th }}$ ed. Elsevier Health Science 2008:162-204

9. Brilakis ES, Mavrogiorgos NC, Kopecky SL, Rihal CC, Gersh BJ, Williams BA, et al. Usefulness of QRS duration in the absence of bundle branch block as an early predictor of survival in non-ST elevation acute myocardial infarction. Am J Cardiol 2002;89(9):1013-18.

10. Attar MN, Wong K, Groves DG, Newall N, Ramsdale DR, Moore RK. Clinical implications of QRS duration and QT peak prolongation in patients with suspected coronary disease referred for elective cardiac catheterization. Ann Noninvasive

Electrocardiol 2008;13(2):106-12

11. Maden O, Kacmaz F, Selcuk MT, Selcuk $H$, Alyan O, Aksu $T$ et al. Relation of admission QRS duration with development of angiographic no-reflow in patients with acute ST-segment elevation myocardial infarction treated with primary percutaneous interventions. J Electrocardiol. 2008;41(1):72-7.

12. Kacmaz F, Maden O, Aksuyek S, Ureyen C, Alyan O, Erbay AR, et al. Relationship of admission QRS duration and changes in QRS duration with myocardial reperfusion in patients with acute ST segment elevation myocardial 
infarction (STEMI) treated with fibrinolytic therapy. Circ J 2008;72(6):873-79.

13. Tsukahara K, Kimura K, Kosuge M, Shimizu T, Sugano T, Hibi K, et al. Clinical implications of intermediate QRS prolongation in the absence of bundle-branch block in patients with STsegment-elevation acute myocardial infarction. Circ J. 2005; 69(1):29-34.

14. Cantor AA, Goldfarb B, llia R. QRS prolongation: a sensitive marker of ischemia during percutaneous transluminal coronary angioplasty. Catheter Cardiovasc Interv 2000;50 (2):177-183

15. van Hellemond IEG, Bouwmeester S, Olson CW, Botker HE, Kaltoft AK, Nielsen SS, et al. Consideration of QRS complex in addition to ST-segment abnormalities in the estimated "risk region" during acute anterior myocardial infarction. J Electrocardiol 2011;44:3706.

16. Ilkay E, Kacmaz F, Maden O, Aksu T, Selcuk MT, Erbay AR, et al. A new electrocardiographic marker of myocardial reperfusion in patients with acute ST-segment elevation myocardial infarction treated with primary
Percutaneous intervention: the value of QRS duration. Eurolntervention 2012;7:1406-12.

17. Suzuki $M$, Saito $M$, Nagai $T$, Saeki $H$, Tatsuno $\mathrm{H}$, Kazatani $\mathrm{Y}$. Association between initial QRS duration and noreflow phenomenon in patients with acute left main coronary artery obstruction. Am J Cardiol 2003;91 (12):1469-71.

18. Sztajsel J, Urban P. Early and late $Q$ wave regression in the setting of acute myocardial infarction. Heart 2000;83:708-10.

19. Weir RAP, Martin TN, Murphy CA, Petrie CJ, Clements S, Steedman T et al. Comparison of serial measurements of infarct size and left ventricular ejection fraction by contrast-enhanced cardiac magnetic resonance imaging and electrocardiographic QRS scoring in reperfused anterior ST-elevation myocardial infarction. J Electrocardiol 2010;43:230-6.

20. Knippenberg SA, Wagner GS, Ubachs JF, et al. Consideration of the impact of reperfusion therapy on the quantitative relationship between the Selvester QRS score and infarct size by cardiac MRI. Ann Noninvasive Electrocardiol 2010;15: 238. 